\title{
Sedimentological characteristics and seafloor failure offshore SW Taiwan
}

\author{
Chih-Chieh $\mathrm{Su}^{1, *}$, Sheng-Ting Hsu ${ }^{1}$, Huai-Houh Hsu ${ }^{2,3}$, Jing-Yi Lin ${ }^{4}$, and Jia-Jyun Dong ${ }^{5}$ \\ ${ }^{1}$ Institute of Oceanography, National Taiwan University, Taipei City, Taiwan \\ ${ }^{2}$ Department of Construction Engineering, National Kaohsiung University of Science and Technology, Kaohsiung City, Taiwan \\ ${ }^{3}$ Department of Civil Engineering, Chienkuo Technology University, Changhua City, Taiwan \\ ${ }^{4}$ Department of Earth Sciences, National Central University, Taoyuan City, Taiwan \\ ${ }^{5}$ Graduate Institute of Applied Geology, National Central University, Taoyuan City, Taiwan
}

\author{
Article history: \\ Received 30 September 2016 \\ Revised 21 June 2017 \\ Accepted 21 June 2017 \\ Keywords: \\ Sedimentation rate, Sediment budget, \\ Submarine canyon, Seafloor failure, \\ $\mathrm{Pb}-210$

\section{Citation:} \\ Su, C.-C., S.-T. Hsu, H.-H. Hsu, J.-Y. \\ Lin, and J.-J. Dong, 2018: Sedimen- \\ tological characteristics and seafloor \\ failure offshore SW Taiwan. Terr. \\ Atmos. Ocean. Sci., 29, 65-76, doi: \\ 10.3319/TAO.2017.06.21.01
}

\begin{abstract}
In this study, analysis results reveal two main deposition zones are located at the flank of upper Gaoping Submarine Canyon and Lower Fangliao Basin offshore SW Taiwan. The non-event related sediments deposited in past 150 years (i.e., $632 \mathrm{Mt} \mathrm{km}^{-2}$ ) was delivered and transported from Gaoping River by suspension process with tides and coastal currents and gradually spread out offshore. Meanwhile, the total mass of accumulation sediments is $1922 \mathrm{Mt} \mathrm{km}^{-2}$, accounting for $40 \%$ Gaoping River's sediment load and suggesting that the deposition process is mainly controlled by natural hazards. Sedimentation rates in much of the study area, except in the main deposition zones, are less than $0.5 \mathrm{~cm} \mathrm{yr}^{-1}\left(5 \mathrm{~m} \mathrm{kyr}^{-1}\right)$. Compared with the studies at the instability seafloor caused by high sedimentation rates $\left(\sim 30 \mathrm{~m} \mathrm{kyr}^{-1}\right)$, the offshore southwestern Taiwan is relatively stable. In this study, we also discovered a series of sediment waves located on the upper continental slope between Gaoping and Fangliao Submarine Canyons, which is related to the creeping process on seafloor. In summary, our results reveal the fluid activities, existence of weak layers and earthquake triggering are potential factors which might induced seafloor failures offshore southwestern Taiwan.
\end{abstract}

\section{INTRODUCTION}

Submarine mass movements or slope failures are controlled by long-term geological preconditioning factors and short-term triggering mechanisms (Leroueil 2001; Locat and Lee 2002; Sultan et al. 2004). For long-term geological preconditioning factors, it includes mass movement history, rapid sediment accumulation and under consolidation, the slope angle, and the existence of a weak layer over long-term climate change (Masson et al. 2006). The short-term triggering mechanisms include slope oversteepening, seismic loading, stormy-wave loading, gas charging, gas hydrate dissociation, low tides, seepage, glacial loading, and volcanic island processes (Locat and Lee 2002). Among these factors and mechanisms, the high sedimentation rates, gas charging, gas hydrate dissociation and seepage are highly related to the overpressure of sediments, which might further decrease the shear resistance of sediments and induce seafloor failures. On

\footnotetext{
* Corresponding author

E-mail:donccsu@ntu.edu.tw
}

the other hand, the characteristics of sediments (i.e., permeability, grain size, and texture) are related to the dissipation of excess pore pressure (Laberg and Camerlenghi 2008). Hence, understanding the sedimentation processes and characteristics of sediments are crucial for seafloor failure studies.

In previous studies (Laberg et al. 2003; Hjelstuen et al. 2004), the noted Storegga and Trænadjupet slides were potentially caused by high sedimentation rates during the glacial period (65 and $36 \mathrm{~m} \mathrm{kyr}^{-1}$, respectively). Moreover, the high deposition rates also led to mass slope failure at the Gulf of Mexico (Solheim et al. 2007; Dugan and Sheahan 2012). Based on the slope stability calculation from the Ursa region in Gulf of Mexico, the overpressures were generated when deposition rates reach $1.5 \mathrm{~cm} \mathrm{yr}^{-1}$. Once the sedimentation rates reach values higher than $3 \mathrm{~cm} \mathrm{yr}^{-1}$, the high overpressure and flow focusing initiated slope failure in the upper 10 mbsf (Stigall and Dugan 2010; Long et al. 2011; Dugan and Sheahan 2012).

In addition to high sedimentation rate, submarine landslides are often observed rooted in the parallel-bedded 
sequences and frequently developed submarine landslides along this weak layer. Weak layers may fail due to high overpressure, sensitive clay, and water content (Solheim et al. 2007). Liquefaction of these layers may further trigger slope instability and served as a detachment plane for seafloor sliding (Kvalstad et al. 2005). The Afen slide which located north-west Shetland Islands was suggested as triggered by seismic induced liquefaction of contouritic sandy sediments (Wilson et al. 2004).

Among the possible triggering mechanisms, earthquake has been regarded as the most important one for submarine landslides up to $40 \%$ (Hance 2003). Earthquakes not only increase the driven stress by seismic accelerations, it also can trigger the liquefaction of cohesionless sediments (Sultan et al. 2004). Three scenarios of earthquake triggered slope failure has been proposed: (1) The excess pore pressure generated by the cyclic stresses degrade the shear strength of sediments and the slope is unable to carry the static shear stress; (2) The increase of excess pore pressure at critical regions caused by seepage from deeper layers; and (3) The post-earthquake failure due to creep, it usually occurred on slopes composed by clay (Nadim 2012).

Over the past decade, under the support of "FATES Integrated Project" (funded by Ministry of Science and Technology; MOST), "Investigation of Gas Hydrate Resource Potential" (funded by Central Geological Survey; CGS), and "Marine Geology and Seabed Stability Study for the Potential Gashydrate Area Off SW Taiwan" (funded by National Energy Program; NEP), we found that the potential submarine geohazards offshore southwestern Taiwan is related to the aforementioned geological preconditioning factors and triggering mechanisms, including sedimentation rate, under consolidation, slope angle, existence of weak layer, climate change history, earthquake, seafloor gas charging, gas hydrate dissociation, and seepage, etc. In this study, the core analysis (including X-ray radiographs, grain size and ${ }^{210} \mathrm{~Pb}$ geochronology) results and chirp sonar images are used to evaluate the seafloor instability offshore southwestern Taiwan.

\section{STUDY AREA AND BACKGROUND}

Taiwan is located in the junction of Eurasia and Philippine Sea Plates developed Ryukyu Arc and Luzon Arc systems along the rim of Western Pacific. The oblique collision between the Luzon Arc and Eurasian continental margin since the Late Miocene has led to the formation of Taiwan Island (Suppe 1981; Ho 1986) and the process is still actively propagating to the south (Suppe 1987). The Manila Trench subduction zone which developed between the South China Sea and the northern Philippines is composed by well-developed accretionary wedge, forearc basin, and the Luzon volcanic arc (Molli and Malavieille 2011). The arc-continent collision in the Taiwan orogen resulted in the western Taiwan foreland basin and including the West- ern Foothill, the Coastal Plain, and the offshore areas which filled more than $5 \mathrm{~km}$ sediments in thickness (Covey 1984; Yu and Chiang 1997).

The offshore area of the southwestern Taiwan is mainly composed of a narrow Gaoping Shelf and broad Gaoping Slope, with water depths ranging from $80-3400 \mathrm{~m}$ (Yu et al. 2009). A series of submarine canyons are incised into Gaoping Shelf and Slope including Gaoping Submarine Canyon (GSC), Fangliao Submarine Canyon (FSC), Kaohsiung Submarine Canyon (KSC), and Shoushan Submarine Canyon (SSC) (Fig. 1). Among them, the GSC and FSC are two major submarine canyon systems which play an important role on delivering sediments from shallow waters to deep sea (Liu et al. 2002; Liu and Lin 2004; Huh et al. 2009; Su et al. 2012).

The GSC extends from the Gaoping River and can be divided into three segments along the canyon. The upper reach segment is located on the Gaoping Shelf and the

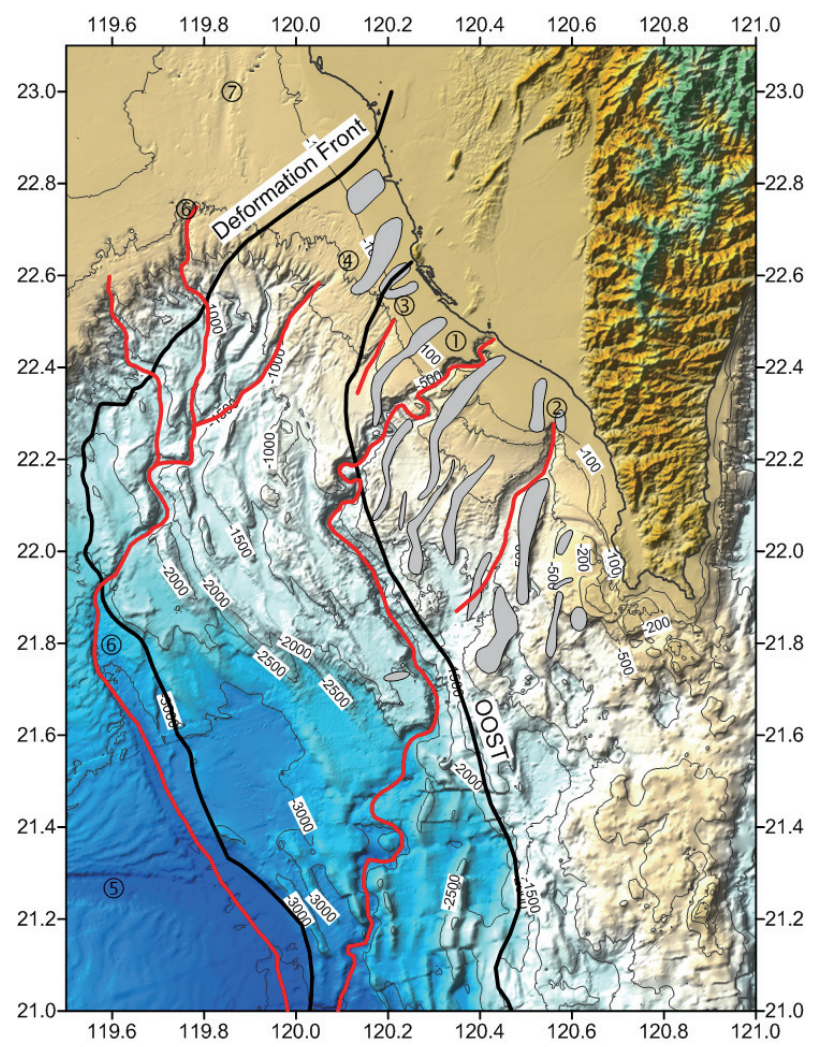

Fig. 1. Map showing the location of geomorphic units and the submarine canyons off SW Taiwan. Six major submarine canyons, (1) Gaoping Submarine Canyon, (2) Fangliao Submarine Canyon, (3) Kaohsiung Submarine Canyon, (4) Shousan Submarine Canyon, (5) Formosa Submarine Canyon, (6) Penghu Submarine Canyon, developed on the Gaoping Shelf and Slope and deep-sea offshore southwestern Taiwan and merged into the north termination of the Manila Trench. The deformation front separates the passive South China Sea (SCS) continental margin in the west and active accretionary wedge in the east. The out-of-sequence thrust (OOST) separates the Lower Gaoping Slope and Upper Gaoping Slope of the accretionary wedge. Mud diapirs are indicated by gray polygons. 
Upper Gaoping Slope, flows southwestward and suddenly turns left when entering the middle reach segment. The middle reach runs straight southeastward, makes a sharp turn into its southwest course, connects to the lower reach which flows sinuously on the Gaoping Deep-sea Fan and finally into the northern Manila Trench (Yu et al. 2009). The morphology of the GSC is strongly controlled by mud diapiric intrusions and the thrust faulting system (Chiang and $\mathrm{Yu}$ 2006; Yu et al. 2009).

The FSC is a relatively small (around $10 \mathrm{~km}$ wide and $60 \mathrm{~km}$ long) and young (<3 Ma) submarine canyon which starts on the Upper Gaoping Slope and extends southward to the base of the upper slope ( $\mathrm{Yu}$ and $\mathrm{Lu}$ 1995). The canyon can be divided into two morphologically contrasting parts. The upper canyon begins at the shelf edge and has no connection to the river onland. The length of the upper canyon is approximately $40 \mathrm{~km}$ between water depths from $100-600 \mathrm{~m}$. In the upper canyon, truncation of parallel flatlying strata and sliding/slumping features on the canyon walls are indicative of downcutting and lateral widening of the canyon ( $\mathrm{Yu}$ and $\mathrm{Lu}$ 1995). In the lower canyon, a rising linear ridge formed by shale diapir separates the canyon into two segments and it extends downslope to about the $1000 \mathrm{~m}$ isobath and connects to the lower reach of GSC (Fig. 1)

\section{MATERIALS AND METHODS}

The box and gravity cores were collected using R/V Ocean Researcher 1 from 2005 - 2015 and the sampling sites are plotted in Fig. 2. The cores were split into working and archive halves, and surface photographs were immediately taken using a high-resolution digital camera at the Core Laboratory of the Taiwan Ocean Research Institute (TORI). Transparent acrylic trays $(25 \times 10 \times 1 \mathrm{~cm})$ were used to take sediment slabs for $\mathrm{X}$-ray radiographic photography. The remaining sediments in the split barrels were sectioned at 1 $\mathrm{cm}$ intervals and sealed in centrifuge tubes for freeze-dried. The X-radiographic images of sediment slabs were taken by AXR Model M160NH Cabinet X-ray machine with digital scanner. The operating condition of the X-ray was set as $4 \mathrm{~mA}$ and $60 \mathrm{kV}$. The integration time for the digital scanner was 100 - $140 \mathrm{~ms}$ and the X-radiographic images were processed using the iX-Pect EZ software that came with the digital X-ray scanner.

The grain size analysis was conducted by using laser diffraction particle size analyzer (Beckman Coulter LS13 320) equipped with auto-sampler. All sediment samples were pre-treated following the USGS procedures (Poppe et al. 2000). The cement and carbonates were removed by using $10 \%$ hydrochloride and carbonate-free samples were treated with $15 \%$ hydrogen peroxide for $1-2$ days to remove organic matter. Ultrasonic devices and sodium hexametaphosphate were used to deflocculate and disperse sediment grains prior to the grain-size analysis.
Lead-210 activity was determined by $\alpha$-spectrometer via its granddaughter nuclide ${ }^{210} \mathrm{Po}$. Polonium-209 spike was added as a yield determinant prior to the total digestion of the samples. Polonium isotopes were plated onto a silver disc from the sample solution (in $1.5 \mathrm{~N} \mathrm{HCl}$, in the presence of ascorbic acid) at $80-90^{\circ} \mathrm{C}$ for approximately $1-2 \mathrm{~h}$. The counting results were corrected for the decay of ${ }^{210} \mathrm{Po}$ (from the time of plating to counting) and ${ }^{210} \mathrm{~Pb}$ (from sample collection to Po plating).

Two different types of sub-bottom echo profiler were used in this study. On Ocean Research 1 cruises, a hullmounted chirp sonar survey by using the ODEC Bathy 2000 p system (the system was upgraded to Bathy 2010p in 2012), which was set at the frequency range $3-11 \mathrm{kHz}$. For some cruises (OR1-942, 951; and OR3-1253, 1262, 1434, 1468), a high resolution EdgeTech 0512i sub-bottom profiling system (set at the frequency range $0.5-12 \mathrm{kHz}$ and towed 5 - $10 \mathrm{~m}$ below the sea surface) was used.

\section{RESULTS AND DISCUSSION}

The tectonic, climatic and geographic location makes Taiwan all the time under threaten of high frequency earthquake and typhoon induced natural hazards on land or offshore. After the 2006 Pingtung Earthquake and 2009

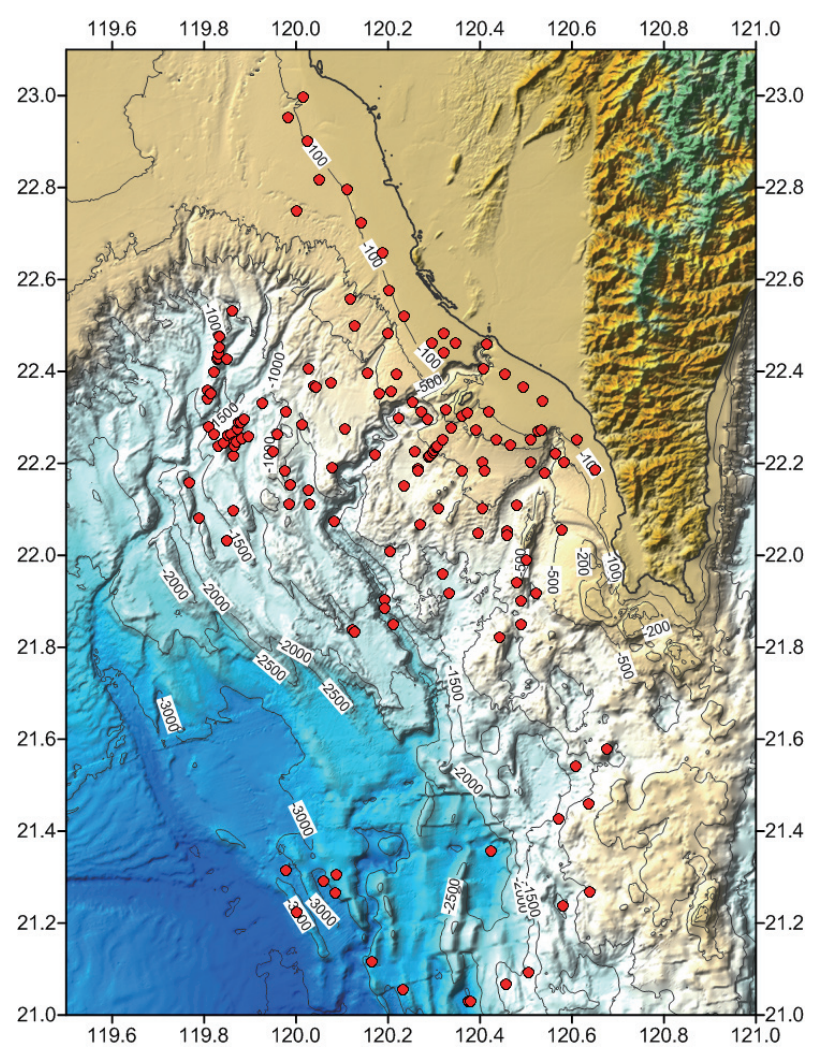

Fig. 2. Locations of the sampling sites collected during 2005 - 2015. Some of the locations have been sampled repeatedly in order to evaluate the evolution of the turbidite layers in the sediments. 
Morakot Typhoon, people realized that the sediment gravity flows triggered by earthquakes, storms and river floods have tremendous destructive power on seafloor infrastructures (Hsu et al. 2008). In addition, since 2004, the Central Geological Survey of Republic of China promoted the first phase of Gas Hydrate Investigation Program. It demonstrated the gas hydrates are widely distributed offshore southwestern Taiwan. The preliminary in-place estimates pointed out the gas hydrate reserves offshore southwestern Taiwan are about 1.5 trillion cubic meters. Although there are no proved reserves for gas hydrates at this time, if $10 \%$ of this is exploitable, it will produces 150 billion cubic meters of natural gas (Chen et al. 2016). Its economic benefits should not be overlooked. Leaving aside its advantages on economic and energy developments, gas hydrates are also a potential risk. Not only because of its main composition, methane, is one of the most potent greenhouse gas, but also the potential of triggering submarine slope failures. Its volume can expends by 150 - 170 times under the Earth surface condition. Therefore, regardless of gas hydrate exploitation or submarine geohazards prevention, seabed stability investigation has to be done without delay.

Currently, the seafloor stability research in Taiwan is still infancy. The in-situ geotechnical explorations only have been done in the shallow waters where the water depth not exceed $100 \mathrm{~m}$. Furthermore, only a few studies mentioned the interaction between various geological processes (Hale et al. 2012; Su et al. 2012). Benefits from the support of the projects funded by MOST, CGS, and NEP, the acquisition of dense and accurate submarine information using different geophysical, geochemical, engineering approaches has opened up new possibilities for improving our understanding of submarine geohazards and potential seafloor instability (Chen et al. 2018; Hsu et al. 2018a, b; Lin et al. 2018). In this study, we combined and demonstrated the most update survey data which were collected during the period from 2005 - 2015, including core analysis results, chirp sonar profiles, and high resolution bathymetry data offshore southwestern Taiwan.

\subsection{Sedimentological Implications}

From 2005 - 2015, over 170 cores were collected by 31 cruises using OR1 and OR3 research vessels (Fig. 2). Grain size, water content, bulk density, ${ }^{210} \mathrm{~Pb}$ activities and inventories were analyzed and integrated. The full dataset are too massive to be fully presented in this paper, and thus the spatial distribution map of median grain size $\left(\mathrm{D}_{50}\right)$, sorting, bulk density, inventories of ${ }^{210} \mathrm{~Pb}_{\mathrm{ex}}$ are used to illustrate salient features and highlight the major points.

\subsubsection{Grain Size}

The spatial distribution of sediment median grain size
$\left(D_{50}\right)$ showed the sediments are mainly composed by $6-7 \phi$, belonging to the fine silt (Fig. 3). The phi unit ( $\phi$, Krumbein phi scale) is a logarithmic scale computed by the equation $\phi=-\log _{2} \mathrm{D}$, where $\mathrm{D}$ is the grain diameter in millimeters. The coarse sediments $(3-5 \phi)$ are distributed on the shelf, Lower Fangliao Basin, and western Hengchun Ridge. The distribution of coarse sediments in the shelf is presumed to be due to the coarse sediment delivered by Tsengwen and Erjen Rivers and the extension of the offshore barrier off Tainan. In the Lower Fangliao Basin, since the FSC has no connection to the river on land, it is speculated that coarse sediments were delivered by earthquake- or flooding-induced gravitational flows (Hale et al. 2012; Su et al. 2012). On the western slope of the Hengchun Ridge, the sediments are mainly composed by slates. Owing to the isolated basins block the transportation of sediments from rivers in southern Taiwan, the provenance of the sediments might be collapsed from the Hengchun Ridge or transported from the southern tip of the Central Mountain Range in Hengchun Peninsula.

Besides the median grain size, the term of sorting describes the degree of uniformity of grain size and provides us a better understanding of the hydrodynamic status during the transportation of sediments. The most striking feature of the spatial distribution of sorting revealed a pair of depositional lobes with good sorting that flank the GSC (Fig. 4). It indicates the flank of GSC and deep-sea basin were mainly composed by suspended deposits.

\subsubsection{Bulk Density}

The spatial distribution of bulk density is closely related to the grain size and water content distributions. Sediments with high bulk densities are observed on the shelf and upper Gaoping Slope (Fig. 5). Compared with the median grain size distribution (Fig. 3), we suggest the coarse-grained sediments were mainly delivered by Tsengwen and Erjen Rivers. On the contrary, sediments with high bulk density at the toe of the upper slope were resulted by seafloor failure induced dewatering.

\subsection{Pb-210 Chronology and Distribution of Inventory}

\subsubsection{Apparent Sedimentation Rates from ${ }^{210} \mathrm{~Pb}$ Profiles}

Fifty four cores were analyzed for ${ }^{210} \mathrm{~Pb}$ to evaluate the sedimentation rates offshore Southwestern Taiwan. In these cores, non-steady state profiles are common and obstructing the use of excess ${ }^{210} \mathrm{~Pb}$ as a geo-chronometer in this study. Considering Taiwan all the time under threaten of high frequency earthquake and typhoon induced natural hazards, it is not unexpected. We illustrated representative ${ }^{210} \mathrm{~Pb}$ profiles for comparing the differences of sedimentation rates in the study area (Fig. 6). The ${ }^{210} \mathrm{~Pb}$-based sedimentation rates were derived by semi-log plots. The apparent sedimentation rates $\left(\mathrm{S}_{\mathrm{Pb}-210}\right)$ can be calculated by $\mathrm{S}_{\mathrm{Pb}-210}=\lambda / \mathrm{m}$, where $\lambda$ and 


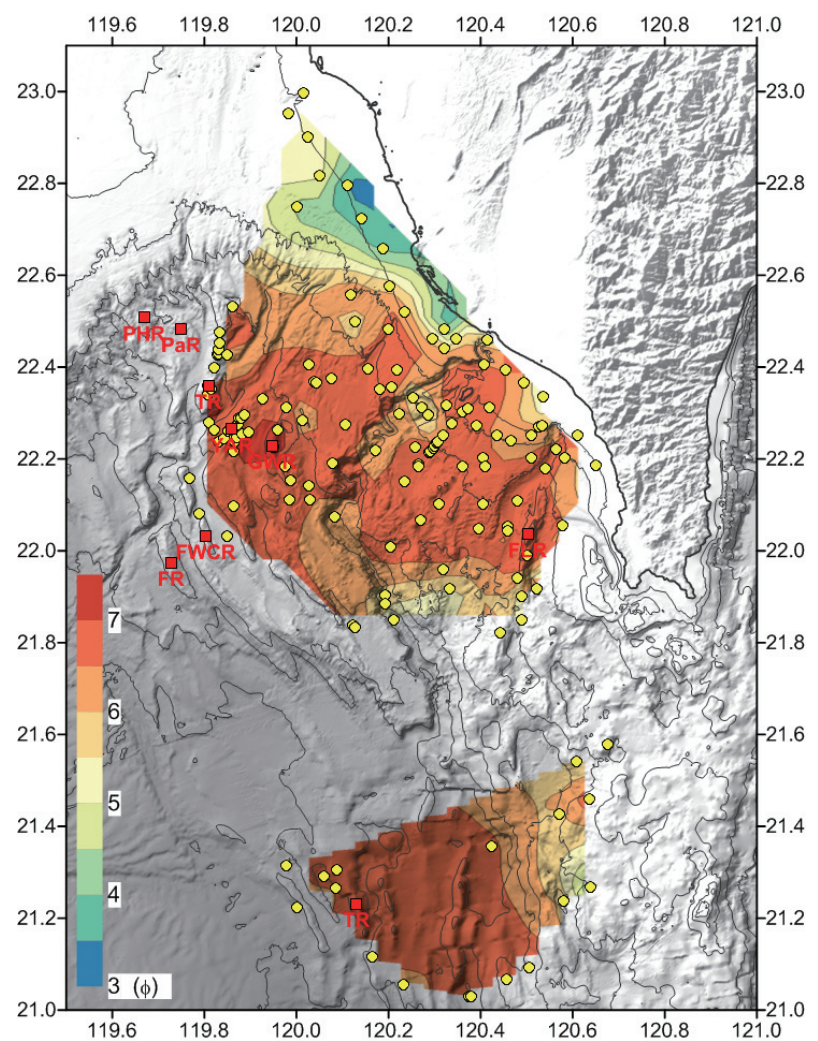

Fig. 3. The spatial distribution of median grain size offshore southwestern Taiwan. The red square is the location of ridges in the study area: PHR - Penghu Ridge; PaR - Palm Ridge; TR - Tainan Ridge; YAR - Yuan-An Ridge; GWR - Good Weather Ridge; FLR - Fangliao Ridge; FWCR Four-Way-Closure Ridge; FR - Frontal Ridge.

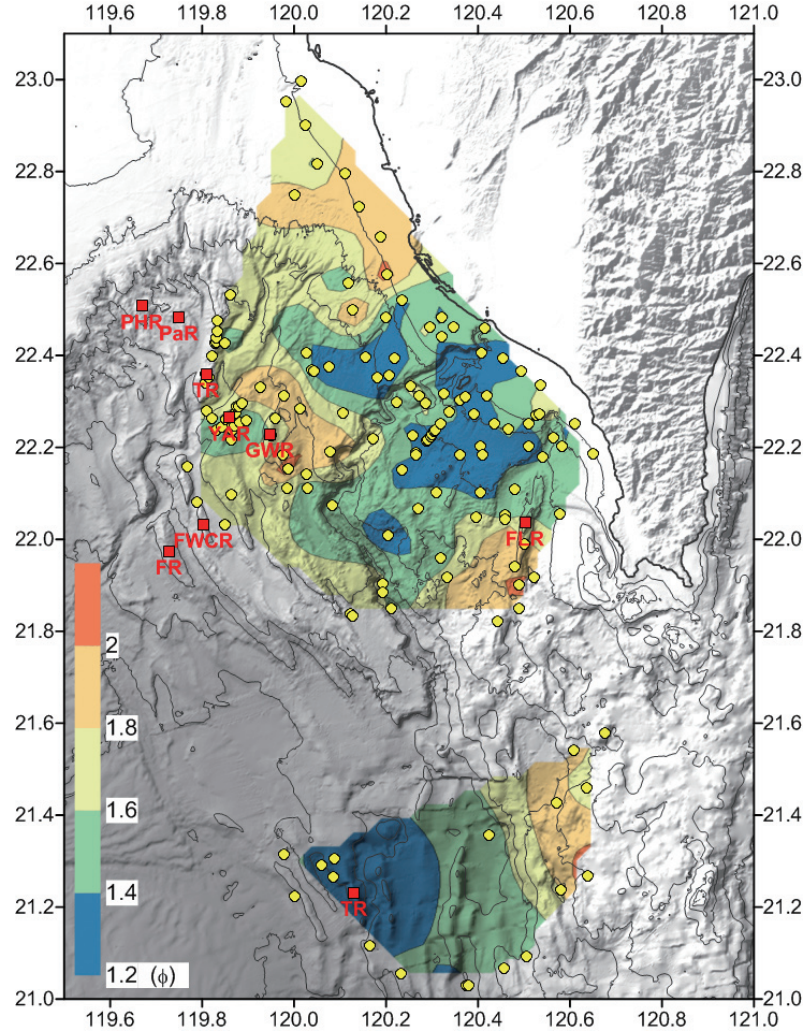

Fig. 4. The spatial distribution of sorting offshore southwestern Taiwan.

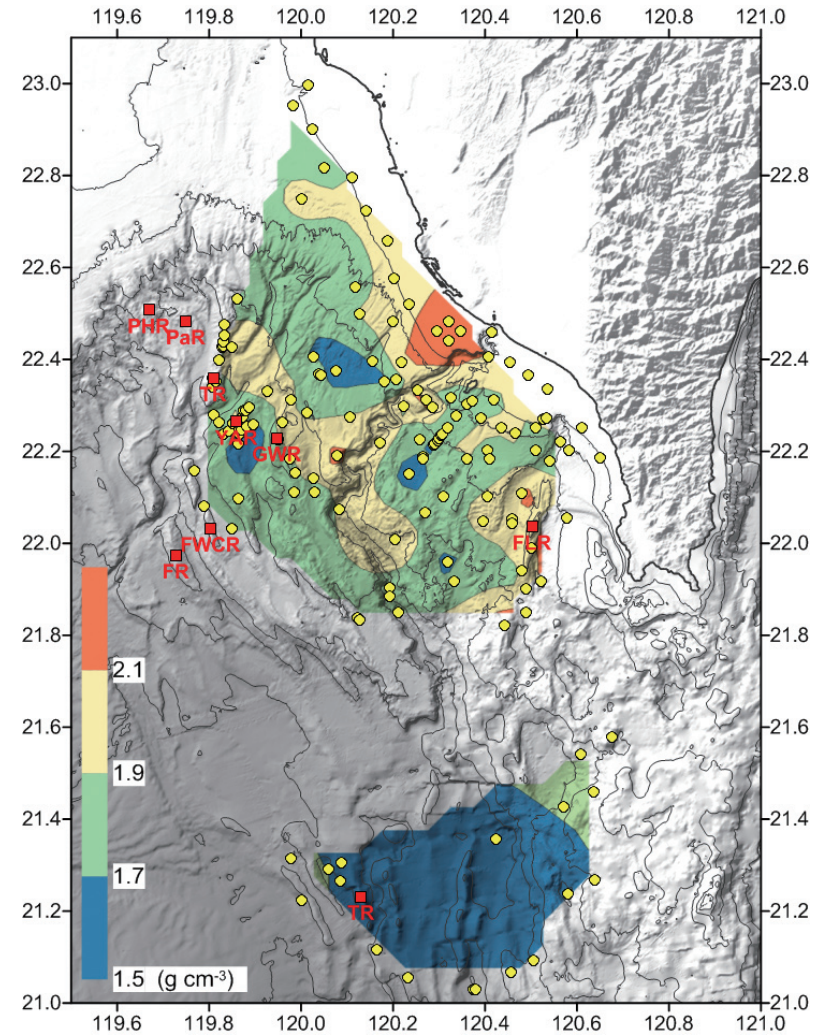

Fig. 5. The spatial distribution of sediment bulk density offshore southwestern Taiwan. 
(a)

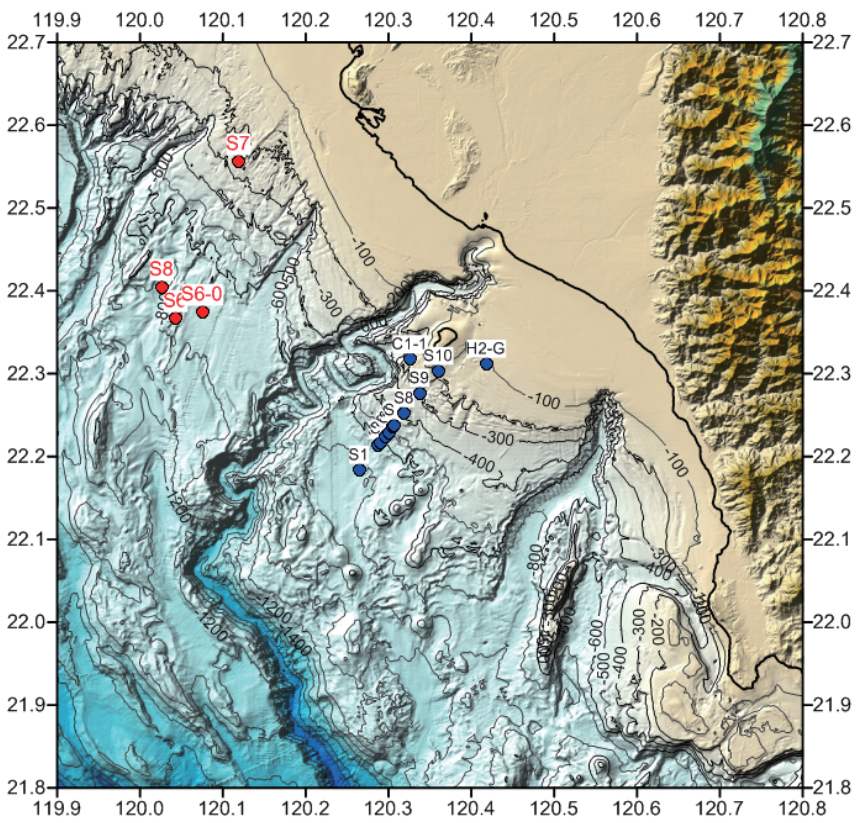

$\begin{array}{llllllll}\text { total } & { }^{210} \mathrm{~Pb}_{\left(\mathrm{dpm} \mathrm{g}^{-1}\right)}\end{array}$
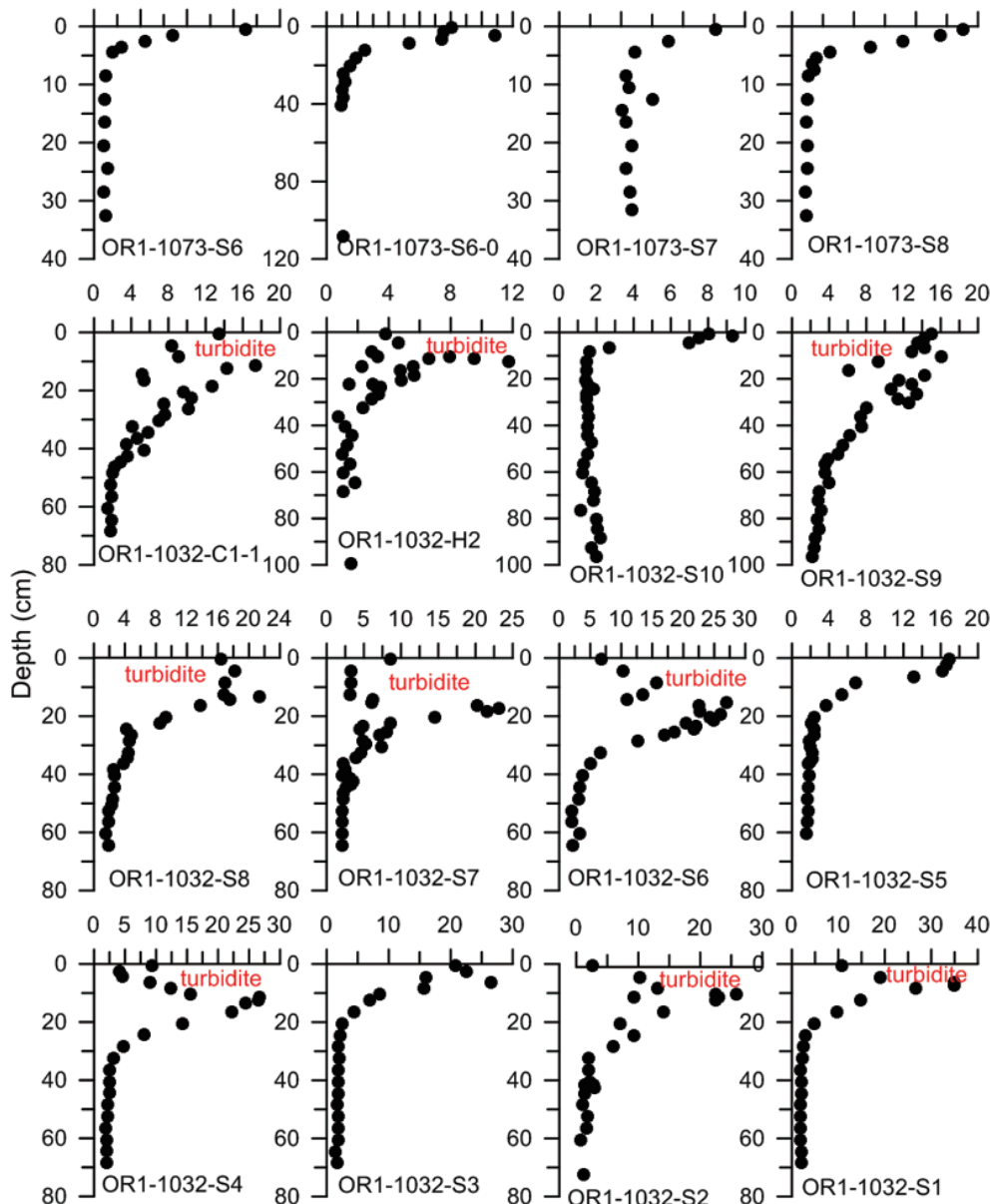

Fig. 6. Examples of ${ }^{210} \mathrm{~Pb}$ profiles in cores collected at the northern and southern Upper Gaoping Slope. (a) The location of cores collected in OR11073 (red dot) and OR1-1032 (blue dot). (b) The ${ }^{210} \mathrm{~Pb}$ activity profiles. 
$\mathrm{m}$ are the decay constant of ${ }^{210} \mathrm{~Pb}\left(0.0311 \mathrm{yr}^{-1}\right)$ and the slope of ${ }^{210} \mathrm{~Pb}_{\text {ex }}$ decrease down core. In the northern Upper Gaoping Slope, the ${ }^{210} \mathrm{~Pb}_{\text {ex }}$ profiles are commonly show good fit to a steady-state sedimentation-decay model. The sedimentation rates are lower than $0.1 \mathrm{~cm} \mathrm{yr}^{-1}$. On the contrary, the cores collected from the southern Upper Gaoping Slope (between GSC and FSC) the ${ }^{210} \mathrm{~Pb}$ profiles reveal the influence of gravity flows induced by typhoon activities (Huh et al. 2009; Su et al. 2012). After excluding the turbidite layers, the sedimentation rates were recalculated by recombining the non-events layers. The recalculated results show that the sedimentation rates are higher in the southern Upper Gaoping Slope and point out the importance of the GSC on transport sediments from land to sea. Overall, from modern sedimentation records, the northern Gaoping Slope is more stable in the last 150 years.

\subsubsection{Spatial Distribution of Excess ${ }^{210} \mathrm{~Pb}$ Inventory}

Compared with the spatial distribution of ${ }^{210} \mathrm{~Pb}$-based sedimentation rates (Huh et al. 2009), it clearly shows the same distribution pattern between excess ${ }^{210} \mathrm{~Pb}$ inventory and sedimentation rates (Fig. 7). Considering the study area is deeply influenced by turbidity currents, hyperpycnal flows, and debris flows (Huh et al. 2009; Hale et al. 2012; Su et al. 2012), non-steady state profiles are frequently obstructing the use of excess ${ }^{210} \mathrm{~Pb}$ as a geo-chronometer. We proposed that the spatial distribution of excess ${ }^{210} \mathrm{~Pb}$ inventory can be used as a substitute proxy of sedimentation rates and it reveals that the sediments discharged from the Gaoping River were mainly deposited on the flank of the GSC, the Lower Fangliao Basin, and along the levee system of the Lower Reach of GSC and its extension to the north terminus of the Manila Trench.

\subsubsection{A Sediment Budget Evaluation Offshore Southwestern Taiwan}

In previous study, Huh et al. (2009) evaluated the sediment budget off the Gaoping River. They estimated in their study area that 6.6 mega tons sediments were annually deposited, accounting for less than $20 \%$ of Gaoping River's sediment load. Considering the difficulties of using excess ${ }^{210} \mathrm{~Pb}$ as a chronometer in non-steady state profiles, we combined with the grain size, cumulative mass and ${ }^{210} \mathrm{~Pb}$ profiles for further evaluation of sediment budget offshore southwestern Taiwan. The sediment budget of non-event related deposits are estimated by ${ }^{210} \mathrm{~Pb}$-based sedimentation rate with steady state profiles as shown in Fig. 8. The total accumulation mass in the past 150 years was derived by integrating the salt-free mass above the total ${ }^{210} \mathrm{~Pb}$ equilibrium with the supported ${ }^{210} \mathrm{~Pb}$ which can be described as

Total Acumulative Mass =

$\sum\left[\rho_{\text {wet }} \times \Delta Z \times\left(1-\frac{1000}{1000-S} \times\right.\right.$ water\% $\left.)\right]$
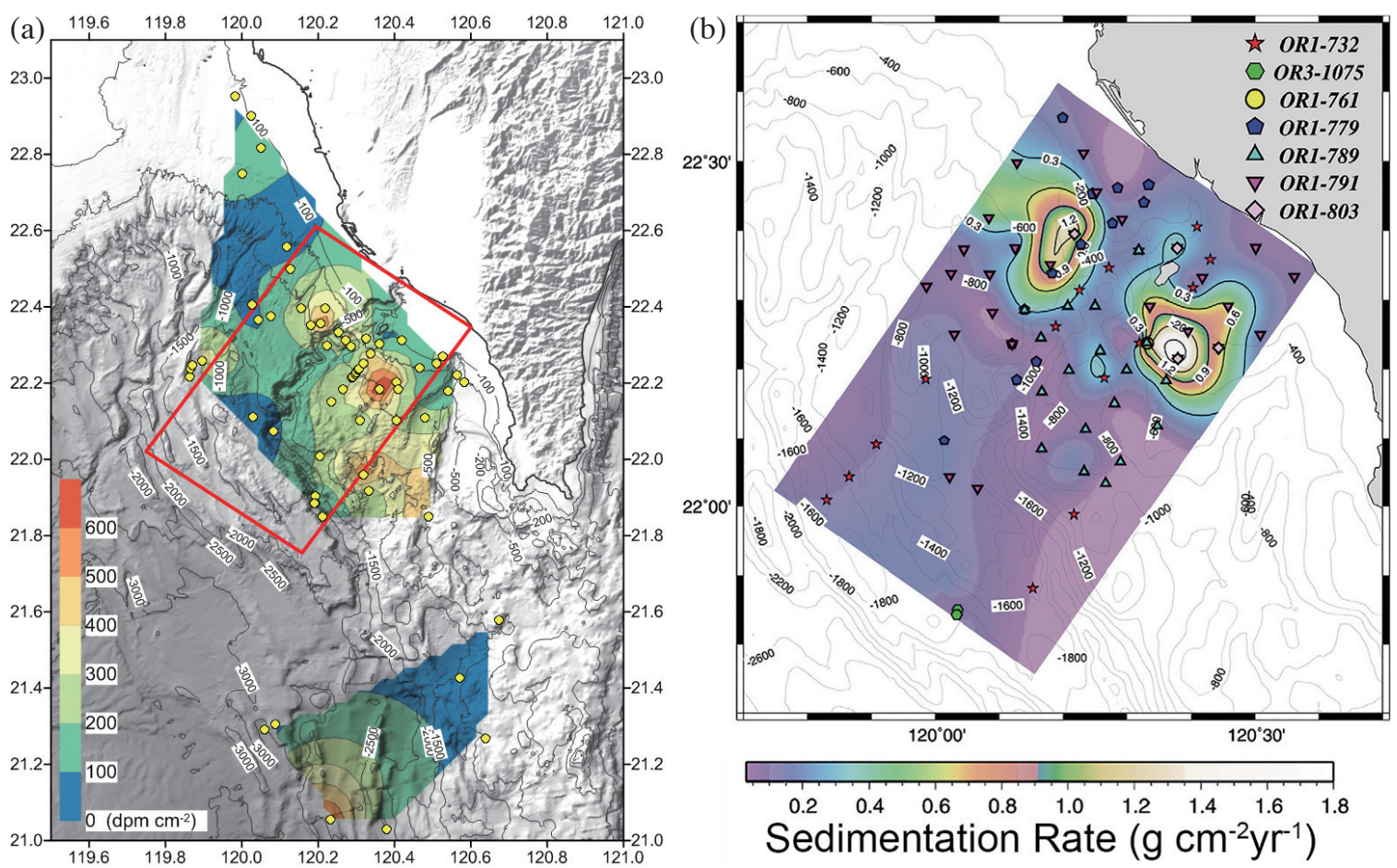

Fig. 7. (a) Spatial distribution of ${ }^{210} \mathrm{~Pb}$ inventory offshore southwestern Taiwan (this study), the red box indicates the study area of Huh et al. (2009). (b) Spatial distribution of ${ }^{210} \mathrm{~Pb}$-based sedimentation rates (Huh et al. 2009). 


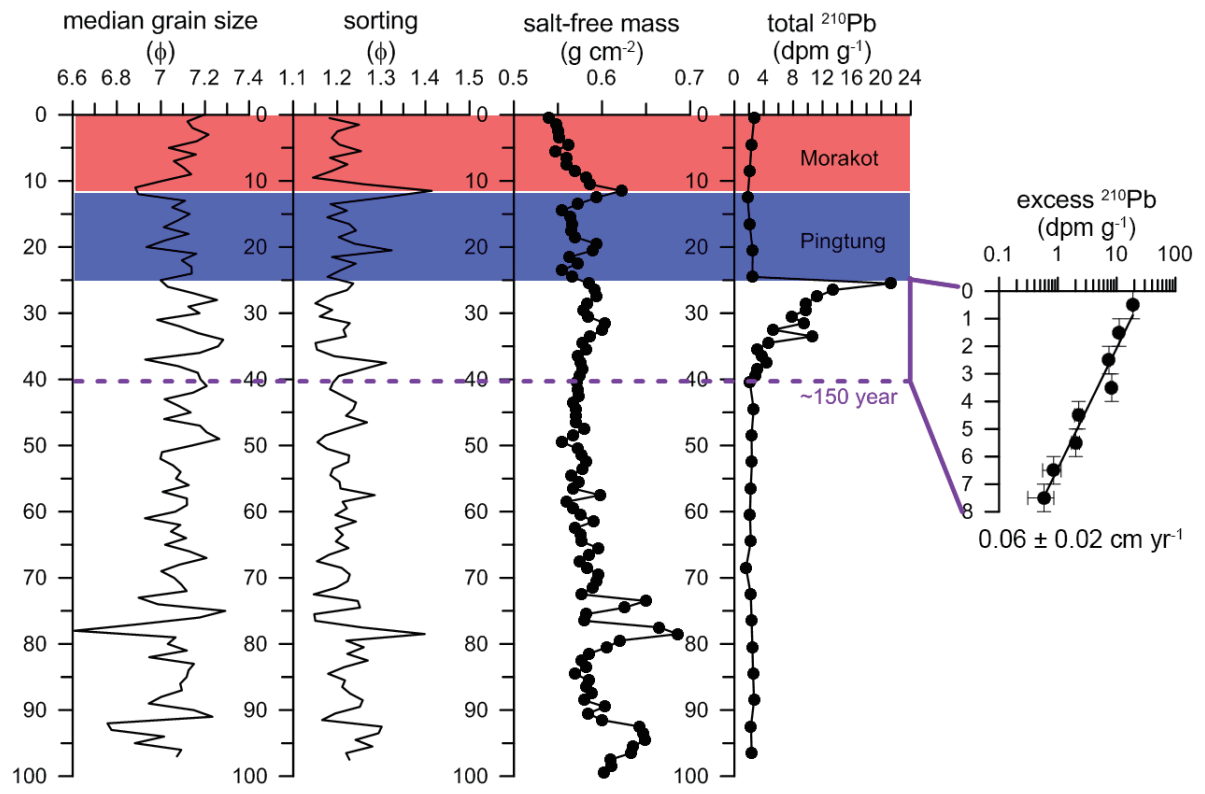

Fig. 8. Examples of sediment budget evaluation. The sediment budget of the non-event period was estimated by the ${ }^{210} \mathrm{~Pb}-\mathrm{based}$ sedimentation rate with steady state profiles. The total accumulation mass is derived by integrated the salt-free mass above the total ${ }^{210} \mathrm{~Pb}$ equilibrium with the supported ${ }^{210} \mathrm{~Pb}$ (dashed line).

where $\rho_{\text {wet }}$ is the bulk density, $\Delta Z$ is the thickness of sediment sample (i.e., $1 \mathrm{~cm}$ in this study), $S$ is the salinity of the pore water, and water\% is the water content.

The spatial distribution of accumulation mass during the non-event period reveals that the sediments were mainly deposited at the middle section of the Upper Reach of GSC (Fig. 9) and the budget of non-event related deposits in Gaoping Shelf and Upper Gaoping Slope in the past 150 years is $632 \mathrm{Mt} \mathrm{km}^{-2}$. According to the ${ }^{210} \mathrm{~Pb}$ profiles, the total budget of sediments (event periods + non-event periods) cumulated in the past 150 years is $1922 \mathrm{Mt} \mathrm{km}^{-2}$, accounting for $40 \%$ of Gaoping River's load and mainly deposited on the Upper Gaoping Slope (Fig. 10). It reveals the sediments offshore southwestern Taiwan are mainly deposited by natural hazards, e.g., earthquakes, heavy rain, and typhoon. Furthermore, the estimated differences between Huh et al. (2009) and this study implies that the event-related sediments are not only distributed along the GSC, it also broadly delivered to the Upper Gaoping Slope. However, the hazard triggered transport process which delivered large amount of sediments into the deep-sea might be underestimated.

\subsection{The Feature of Mass Slope Failure on the Upper Gaoping Slope}

In previous studies, the mass slope failure frequently resulted from the high sedimentation rates (Laberg et al. 2003; Hjelstuen et al. 2004; Solheim et al. 2007; Dugan and Sheahan 2012). Based on slope stability calculation from the Gulf of Mexico, when the sedimentation rates exceed
$30 \mathrm{~m} \mathrm{kyr}^{-1}\left(3 \mathrm{~cm} \mathrm{yr}^{-1}\right)$, the high overpressure disrupts the seafloor (Dugan and Sheahan 2012). Our study points out that the sedimentation rates offshore southwestern Taiwan are less than $0.5 \mathrm{~cm} \mathrm{yr}^{-1}\left(5 \mathrm{~m} \mathrm{kyr}^{-1}\right)$, which is comparatively stable. However, a series of sediment waves were observed between the GSC and FSC. From high resolution bathymetry map (Fig. 11), the most striking feature revealed is the rugged seafloor topography along $200-300$ and $400-600 \mathrm{~m}$ water depths, respectively. The chirp sonar profiles across the north Upper Gaoping Slope (Line01) and south Upper Gaoping Slope (Line02) reveal the retrogressive submarine slump with liquefaction structures under the seafloor ending at $200 \mathrm{~m}$ water depth and landslide deposits occurring below 300 water depth which might have been generated by the massive slope failure at $200-300 \mathrm{~m}$ water depth.

In the past decade, the investigation results from multichannel seismic reflection, chirp sonar and echo sounder profiles point out that fluid activities are frequently observed offshore southwestern Taiwan (Chen et al. 2010; Su et al. 2012; Hsu et al. 2013). The fluid or gas plume located at shallow waters result mainly from submarine groundwater discharge (Su et al. 2012) usually forming the weak layers with wipe-out characteristics in chirp sonar profiles. On the contrary, for depth larger than $500 \mathrm{~m}$ water depth, it may be related to the submarine mud volcanoes, mud diapirs, or gas hydrate-related seepage activities. The sedimentary strata associated with fluid activities are often accompanied with high overpressures. They are prone to initiate slope failures or seafloor liquefactions during earthquake or stormy wave loading. They may induce turbidity or debris flows that 


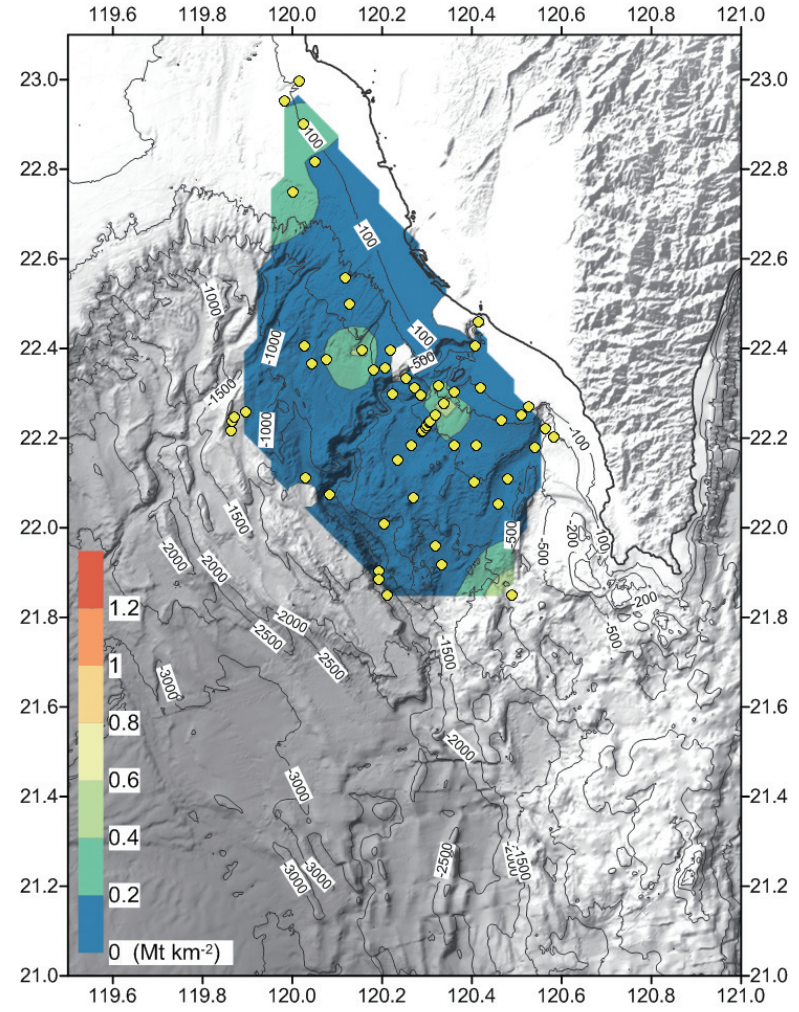

Fig. 9. The spatial distribution of non-event related sediment budget in the last 150 years. The same color scale is used in Figs. 9 and 10 for comparing the differences between these two figures.

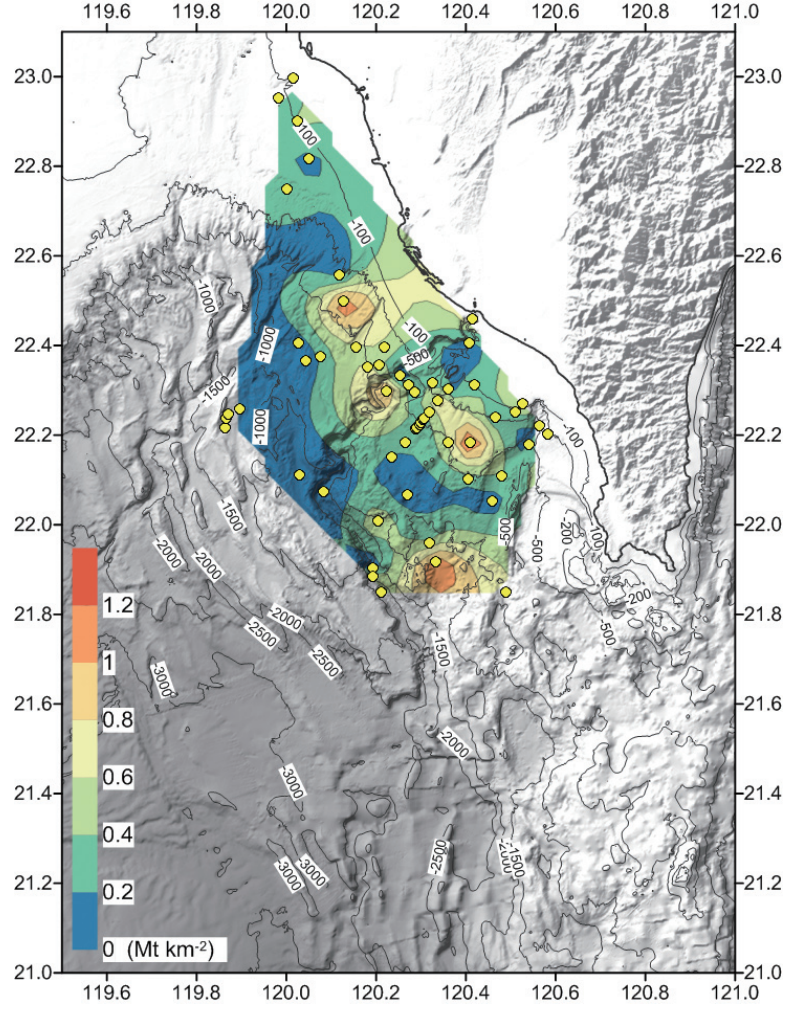

Fig. 10. The spatial distribution of total sediment budget in the last 150 years. The same color scale is used in Figs. 9 and 10 for comparing the differences between these two figures.

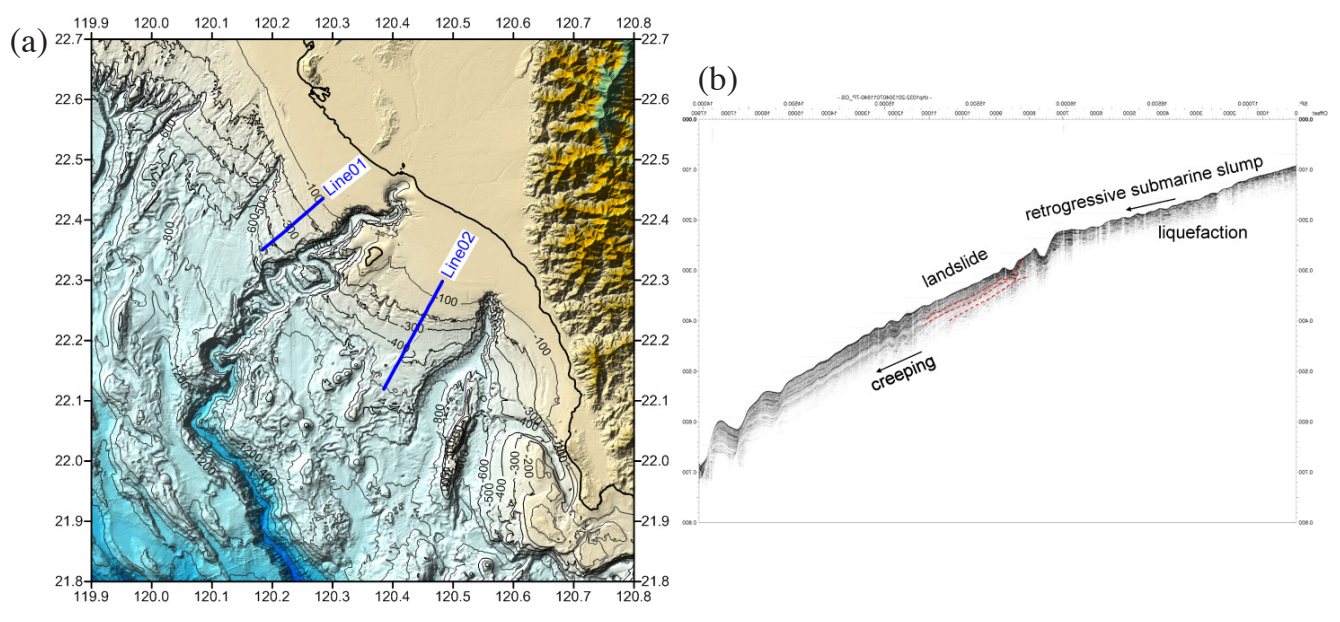

(c) $" \mathrm{~W}$

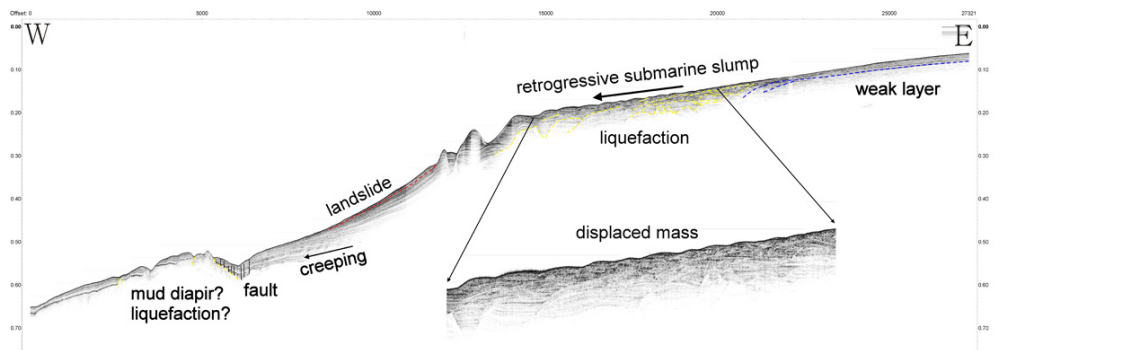

Fig. 11. (a) Map indicates the location of two chirp sonar profiles across the Upper Gaoping Canyon. (b) Line01: the northern Upper Gaoping Slope profile. (c) Line02: the southern Upper Gaoping Slope profile. 
destruct the infrastructure on the seafloor.

\section{CONCLUSION}

Based on data collected during 2005 - 2015 cruises, over 170 cores and long distance chirp sonar profiles were analyzed offshore southwestern Taiwan. Integrating all the detailed works lead us to the following conclusions:

(1) The spatial distribution of bulk density shows that it is lower at the head of Fangliao Submarine Canyon, Upper Gaoping Slope, Yuan-An Ridge, and the Four-WayClosure Ridge. These locations (especially the head of the Fangliao Submarine Canyon and the Upper Gaoping Submarine Canyon) are areas affected by the liquefaction and slumping processes. It indicates that the spatial distribution of bulk density can be used as an effective method for preliminary assessment of the seafloor stability.

(2) Based on the ${ }^{210} \mathrm{~Pb}$ geochronology method, ${ }^{210} \mathrm{~Pb}_{\text {ex }}$ profiles show a good fit to a steady-state sedimentation-decay model in the northern Upper Gaoping Slope and the sedimentation rates are lower than $0.1 \mathrm{~cm} \mathrm{yr}^{-1}$. On the contrary, the ${ }^{210} \mathrm{~Pb}$ profiles reveal the influence of gravity flows induced by typhoon activities with higher sedimentation rates in the cores collected from the southern Upper Gaoping Slope.

(3) From modern sedimentation records, the stability of northern Upper Gaoping Slope is higher than southern Upper Gaoping Slope.

(4) In the past 150 years, $1922 \mathrm{Mt} \mathrm{km}^{-2}$ sediments were accumulated offshore southwestern Taiwan, accounting for $40 \%$ of Gaoping River's load. The difference between event and non-event related sediment budgets indicate the sediments are mainly deposited by natural hazards (earthquakes or typhoon) triggered events. Compare with previous study, the sediments are not only distributed along the Gaoping Submarine Canyon, it is also broadly delivered to the Upper Gaoping Slope.

(5) The high resolution bathymetry and chirp sonar profiles indicate that massive slope failure occurred along the $200-300$ and $500-600 \mathrm{~m}$ water depth. The retrogressive submarine slump with liquefaction structures under the seafloor ends at $200 \mathrm{~m}$ water depth and landslide deposits occurred below 300 water depths which may be generated by the massive slope failure at $200-300 \mathrm{~m}$ water depth.

Acknowledgements The National Energy Program (NEP), FATES Integrated Project, Ministry of Science and Technology (MOST), and Central Geological Survey (CGS) of Taiwan, ROC, provided funding for this research. We thank the captains and crew of R/V Ocean Researcher 1 and Ocean Researcher 3 for shipboard assistance, as well as the assistance in the laboratory of Core Laboratory (Dr. P.-S. You,
Miss J.-R. Liao, and Miss T.-T. Chen) at the Taiwan Ocean Research Institute, National Applied Research Laboratories. We appreciate the constructive reviews by two anonymous reviewers that greatly improved the manuscript.

\section{REFERENCES}

Chen, S.-C., S.-K. Hsu, C.-H. Tsai, C.-Y. Ku, Y.-C. Yeh, and Y. Wang, 2010: Gas seepage, pockmarks and mud volcanoes in the near shore of SW Taiwan. Mar. Geophys. Res., 31, 133-147, doi: 10.1007/s11001-0109097-6. [Link]

Chen, S.-C., S.-H. Chung, Y.-S. Wang, C.-Y. Wei, and P.C. Chen, 2016: Investigation of Gashydrate in Taiwan. Science Development, 524, 6-11. (in Chinese)

Chen, S.-C., C.-H. Tsai, S.-K. Hsu, Y.-C. Yeh, C.-S. Liu, S.-H. Chung, and C.-Y. Wei, 2018: Fangliao Slide a large slope failure in the upper Kaoping Slope off southwest Taiwan. Terr. Atmos. Ocean. Sci., 29, 1730, doi: 10.3319/TAO.2017.06.14.01. [Link]

Chiang, C.-S. and H.-S. Yu, 2006: Morphotectonics and incision of the Kaoping submarine canyon, SW Taiwan orogenic wedge. Geomorphology, 80, 199-213, doi: 10.1016/j.geomorph.2006.02.008. [Link]

Covey, M. C., 1984: Sedimentary and tectonic evolution of the western Taiwan foredeep. Ph.D. Thesis, Princeton University, Princeton, New Jersey, USA, 151p.

Dugan, B. and T. C. Sheahan, 2012: Offshore sediment overpressures of passive margins: Mechanisms, measurement, and models. Rev. Geophys., 50, RG3001, doi: 10.1029/2011RG000379. [Link]

Hale, R. P., C. A. Nittrouer, J.T. Liu, R. G. Keil, and A. S. Ogston, 2012: Effects of a major typhoon on sediment accumulation in Fangliao Submarine Canyon, SW Taiwan. Mar. Geol., 326-328, 116-130, doi: 10.1016/j. margeo.2012.07.008. [Link]

Hance, J. J., 2003: Submarine Slope Stability. The University of Texas at Austin, Austin.

Hjelstuen, B. O., H. P. Sejrup, H. Haflidason, K. Berg, and P. Bryn, 2004: Neogene and Quaternary depositional environments on the Norwegian continental margin, $62^{\circ} \mathrm{N}-68^{\circ}$ N. Mar. Geol., 213, 257-276, doi: 10.1016/j. margeo.2004.10.009. [Link]

Ho, C. S., 1986: An introduction to the geology of Taiwan: explanatory text for the geologic map of Taiwan. Ministry of Economic Affairs, Taipei, Taiwan, Republic of China, 164 pp.

Hsu, H.-H., J.-J. Dong, S.-K. Hsu, and C.-C. Su, 2018: Back analysis of an earthquake-triggered submarine landslide near the SW of Xiaoliuqiu. Terr. Atmos. Ocean. Sci., 29, 77-85, doi: 10.3319/TAO.2017.05.08.01. [Link]

Hsu, S.-K., J. Kuo, C.-L. Lo, C.-H. Tsai, W.-B. Doo, C.-Y. $\mathrm{Ku}$, and J.-C. Sibuet, 2008: Turbidity currents, submarine landslides and the 2006 Pingtung earthquake off 
SW Taiwan. Terr. Atmos. Ocean. Sci., 19, 767-772, doi: 10.3319/TAO.2008.19.6.767(PT). [Link]

Hsu, S.-K., S.-Y. Wang, Y.-C. Liao, T. F. Yang, S. Jan, J.-Y. Lin, and S.-C. Chen, 2013: Tide-modulated gas emissions and tremors off SW Taiwan. Earth Planet. Sci. Lett., 369-370, 98-107, doi: 10.1016/j. eps1.2013.03.013. [Link]

Hsu, S.-K., S.-S. Lin, S.-Y. Wang, C.-H. Tsai, W.-B. Doo, S.-C. Chen, J.-Y. Lin, Y.-C. Yeh, H.-F. Wang, and C.-W. Su, 2018: Seabed gas emissions and submarine landslides off SW Taiwan. Terr. Atmos. Ocean. Sci., 29, 7-15, doi: 10.3319/TAO.2016.10.04.01. [Link]

Huh, C.-A., H.-L. Lin, S. Lin, and Y.-W. Huang, 2009: Modern accumulation rates and a budget of sediment off the Gaoping (Kaoping) River, SW Taiwan: A tidal and flood dominated depositional environment around a submarine canyon. J. Mar. Syst., 76, 405-416, doi: 10.1016/j.jmarsys.2007.07.009. [Link]

Kvalstad, T. J., F. Nadim, A. M. Kaynia, K. H. Mokkelbost, and P. Bryn, 2005: Soil conditions and slope stability in the Ormen Lange area. Mar. Petrol. Geol., 22, 299310, doi: 10.1016/j.marpetgeo.2004.10.021. [Link]

Laberg, J. S. and A. Camerlenghi, 2008: The Significance of Contourites for Submarine Slope Stability. In: Rebesco, M. and A. Camerlenghi (Eds.), Developments in Sedimentology, Volume 60, Elsevier, 537-556, doi: 10.1016/s0070-4571(08)10025-5. [Link]

Laberg, J. S., T. O. Vorren, J. Mienert, H. Haflidason, P. Bryn, and R. Lien, 2003: Preconditions Leading to the Holocene Trænadjupet Slide Offshore Norway. In: Locat, J., J. Mienert, and L. Boisvert (Eds.), Submarine Mass Movements and Their Consequences, Advances in Natural and Technological Hazards Research, Springer Netherlands, 247-254, doi: 10.1007/978-94010-0093-2_28. [Link]

Leroueil, S., 2001: Natural slopes and cuts: Movement and failure mechanisms. Géotechnique, 51, 197-243, doi: 10.1680/geot.2001.51.3.197. [Link]

Lin, J.-Y., Y.-F. Chen, C.-C. Su, S.-J.Chin, W .-B.Cheng, W .N. Wu, C.-W. Liang, H.-S. Hsieh, S.-K. Hsu, and Y.-C. Lin, 2018: Seismic site response of submarine slope offshore southwestern Taiwan. Terr. Atmos. Ocean. Sci., 29, 51-63, doi: 10.3319/TAO.2017.05.09.01. [Link]

Liu, J. T. and H.-L. Lin, 2004: Sediment dynamics in a submarine canyon: A case of river-sea interaction. Mar. Geol., 207, 55-81, doi: 10.1016/j.margeo.2004.03.015. [Link]

Liu, J. T., K. J. Liu, and J. C. Huang, 2002: The effect of a submarine canyon on the river sediment dispersal and inner shelf sediment movements in southern Taiwan. Mar. Geol., 181, 357-386, doi: 10.1016/s00253227(01)00219-5. [Link]

Locat, J. and H. J. Lee, 2002: Submarine landslides: advances and challenges. Can. Geotech. J., 39, 193-212. doi: 10.1139/T01-089. [Link]

Long, H., P. B. Flemings, J. T. Germaine, and D. M. Saffer, 2011: Consolidation and overpressure near the seafloor in the Ursa basin, deepwater Gulf of Mexico. Earth Planet. Sci. Lett., 305, 11-20, doi: 10.1016/j. eps1.2011.02.007. [Link]

Masson, D. G., C. B. Harbitz, R. B. Wynn, G. Pedersen, and F. Løvholt, 2006: Submarine landslides: processes, triggers and hazard prediction. Phil. Trans. Roy. Soc. Lond. Math. Phys. Sci., 364, 2009-2039, doi: 10.1098/ rsta.2006.1810. [Link]

Molli, G. and J. Malavieille, 2011. Orogenic processes and the Corsica/Apennines geodynamic evolution: insights from Taiwan. Int. J. Earth Sci., 100, 1207-1224, doi: 10.1007/s00531-010-0598-y. [Link]

Nadim, F., 2012: Risk Assessment for Earthquake-Induced Submarine Slides. In: Yamada, Y., K. Kawamura, K. Ikehara, Y. Ogawa, R. Urgeles, D. Mosher, J. Chaytor, and M. Strasser (Eds.), Submarine Mass Movements and Their Consequences, Springer, Dordrecht, 15-27, doi: 10.1007/978-94-007-2162-3_2. [Link]

Poppe, L. J., A. H. Eliason, J. J. Fredericks, R. R. Rendigs, D. Blackwood, and C. F. Polloni, 2000: Chapter 1: Grain size analysis of marine sediments: Methodology and data processing. In: Poppe, L. J. and C. F. Polloni (Eds.), USGS East-coast Sediment Analysis: Procedures, Database, and Georeferenced Displays, US Geological Survey Open-File Report, 00-358 (CD-ROM). Available at https://pubs.usgs.gov/of/2000/of00-358/ text/chapter1.htm.

Solheim, A., C. F. Forsberg, S. Yang, T. J. Kvalstad, O. Longva, and L. Rise, 2007: The Role of Geological Setting and Depositional History in Offshore Slope Instability. Offshore Technology Conference, doi: 10.4043/18720-ms. [Link]

Stigall, J. and B. Dugan, 2010: Overpressure and earthquake initiated slope failure in the Ursa region, northern Gulf of Mexico. J. Geophys. Res., 115, B04101, doi: 10.1029/2009JB006848. [Link]

Su, C.-C., J.-Y. Tseng, H.-H. Hsu, C.-S. Chiang, H.-S. Yu, S. Lin, and J. T. Liu, 2012: Records of submarine natural hazards off SW Taiwan. Geol. Soc. Lond. Spec. Publ., 361, 41-60, doi: 10.1144/SP361.5. [Link]

Sultan, N., P. Cochonat, M. Canals, A. Cattaneo, B. Dennielou, H. Haflidason, J. S. Laberg, D. Long, J. Mienert, F. Trincardi, R. Urgeles, T. O. Vorren, and C. Wilson, 2004: Triggering mechanisms of slope instability processes and sediment failures on continental margins: A geotechnical approach. Mar. Geol., 213, 291-321, doi: 10.1016/j.margeo.2004.10.011. [Link]

Suppe, J., 1981: Mechanics of mountain building and metamorphism in Taiwan. Mem. Geol. Soc. China, 4, 67-89.

Suppe, J., 1987: The active Taiwan mountain belt. In: Schaer, J. P. and J. Rogers (Eds.), The Anatomy of Mountain 
Ranges, Princeton University Press, Princeton, New Jersey, USA, 277-294, doi: 10.1515/9781400858644.277. [Link]

Wilson, C. K., D. Long, and J. Bulat, 2004: The morphology, setting and processes of the Afen Slide.Mar. Geol., 213, 149-167, doi: 10.1016/j.margeo.2004.10.005. [Link]

Yu, H.-S. and C.-S. Chiang, 1997: Kaoping Shelf: Morphology and tectonic significance. J. Asian Earth Sci., 15, 9-18, doi: 10.1016/S0743-9547(96)00076-1. [Link]
Yu, H.-S. and J. C. Lu, 1995: Development of the shale diapir-controlled Fangliao Canyon on the continental slope off southwestern Taiwan. J. Southeast Asian Earth Sci., 11, 265-276, doi: 10.1016/0743-9547(95)00004C. [Link]

Yu, H.-S., C.-S. Chiang, and S.-M. Shen, 2009: Tectonically active sediment dispersal system in SW Taiwan margin with emphasis on the Gaoping (Kaoping) Submarine Canyon. J. Mar. Syst., 76, 369-382, doi: 10.1016/j. jmarsys.2007.07.010. [Link] 